\title{
PERAN LPKSM AL-JABBAR DALAM PENYELESAIAN SENGKETA JAMINAN FIDUSIA DI KABUPATEN SUMEDANG
}

\author{
Acep Fahmi Abdulah Salam \\ Fakultas Syariáh dan Hukum UIN Sunan Gunung Djati Bandung \\ Email: acepfahmiabdulahsalam@gmail.com
}

\begin{abstract}
Abstrak
Lembaga Perlindungan Konsumen Swadaya Masyarakat (LPKSM) AlJabbar dibentuk berdasarkan Pasal 44 Undang-undang Nomor 8 Tahun 1999 tentang Perlindungan Konsumen. Lembaga ini, sebagaimana terjabar dalam pasal tersebut berfungsi sebagai penerima aspirasi atau keluhan konsumen yang dirugikan serta menangani masalah penyelesaian sengketa konsumen dan pelaku usaha. Salah satu penyelesaian sengketa yang dilakukan lembaga tersebut adalah sengketa fidusia. Tulisan ini mendeskripsikan bagaimana LPKSM tersebut melaksanakan tugasnya dalam penyelesaan sengketa fidusia antara pelaku usaha dengan konsumennya. Dari analisis normatif ditemukan bahwa lembaga tersebut belum menerapkan secara utuh ketentuan dalam undang-undang yang memayungi berdirinya lembaga tersebut.
\end{abstract}

Kata Kunci:

Perlindungan Konsumen, LPKSM, Penyelesaian Sengketa

\section{Pendahuluan}

Kegiatan bisnis terdapat hubungan yang saling membutuhkan antara pelaku usaha dengan konsumen (pemakai barang dan atau jasa). Kepentingan pelaku usaha adalah memperoleh laba dari transaksi dengan konsumen, sedangkan kepentingan konsumen adalah memperoleh kepuasan melalui pemenuhan kebutuhannya terhadap produk tertentu. Hubungan demikian seringkali terdapat ketidak seimbangan antara keduanya. Konsumen biasanya berada pada posisi tawar yang lemah, karenanya sering menjadi sasaran eksploitasi pelaku usaha yang secara sosial dan ekonomi memiliki posisi yang kuat. Kelemahan konsumen dibandingkan dengan pelaku usaha dapat terlihat pada faktor ekonomi, pengetahuan, psikologis, maupun pendi- 
dikan. Menurut hasil penelitian BPHN (Badan dan Pembinaan Hukum Nasional), faktor-faktor penyebab lemahnya konsumen juga dapat muncul karena hal-hal sebagai berikut:1

Pertama, masih rendahnya tingkat kesadaran konsumen akan haknya. Kedua, belum terkondisinya masyarakat konsumen karena masyarakat belum tahu hak-hak dan kemana hak-haknya disalurkan jika mendapatkan kesulitan atau kekurangan dari standar barang atau jasa yang sewajarnya. Ketiga, belum terkondisinya masyarakat konsumen menjadi masyarakat yang mempunyai kemauan menuntut hak-haknya. Keempat, proses peradilan yang ruwet dan waktu yang berkepanjangan. Kelima, posisi konsumen yang lemah.

Fenomena yang tidak seimbang menempatkan konsumen cenderung dijadikan objek aktivitas bisnis dari pelaku usaha untuk memperoleh keuntungan sebesar-besarnya melalui iklan, promosi, cara penjualan serta penerapan perjanjian standar yang merugikan konsumen.

Untuk melindungi atau memberdayakan konsumen diperlukan adanya campur tangan negara melalui penetapan sistem perlindungan hukum terhadap konsumen. ${ }^{2}$

Untuk melindungi konsumen dibutuhkan lembaga khusus yang dapat melindungi konsumen baik yang dibentuk oleh swadaya masyarakat maupun yang dibentuk oleh pemerintah, dimana lembaga tersebut berfungsi melindungi konsumen dari perbuatan pelaku usaha yang tidak beritikad baik.

Seiring berjalannya waktu untuk membantu konsumen Indonesia agar tidak dirugikan oleh pelaku usaha dalam mengkonsumsi barang dan/atau jasa dan agar dapat membantu konsumen dalam menyelesaikan sengketa dengan pelaku usaha muncul Lembaga Perlindungan Konsumen Swadaya Masyarakat (yang selanjutnya akan di singkat menjadi LPKSM) yang dibentuk oleh masyarakat itu sendiri.

Peran LPKSM dalam menyelesaikan sengketa konsumen diatur secara khusus dalam Pasal 44 ayat (2) Undang-Undang Nomor 8 Tahun 1999 tentang Perlindungan Konsumen (yang selanjutnya disebut UUPK) bahwa "Lembaga Perlindungan Konsumen Swadaya

\footnotetext{
${ }^{1}$ Intar Nur dan Rukiyah Lubis, Win-Win Solution Sengketa Konsumen, Pustaka Yustisia, Yogyakarta, 2014, hlm. 44

2 Sanusi Bintang dan Dahlan, Pokok-Pokok Hukum Ekonomi dan Bisnis, PT. Citra Aditya Bakti, Bandung, 2000, hlm 107
} 
Masyarakat memiliki kesempatan untuk berperan aktif dalam mewujudkan perlindungan konsumen".

Sehubungan dengan penjaminan, apa yang harus dilakukan oleh penerima fidusia (kreditor) apabila pemberi fidusia (debitor) melalaikan kewajibannya atau cidera janji yang berupa lalainya pemberi fidusia (debitor) memenuhi kewajibannya, maka penerima fidusia (kreditor) bisa melaksanakan eksekusi atas benda jaminan fidusia. ${ }^{3}$ Perlu disepakati terlebih dahulu bahwa yang dinamakan eksekusi adalah pelaksanaan keputusan pengadilan atau akta. Tujuan eksekusi adalah pengambilan pelunasan kewajiban debitor melalui hasil penjualan benda-benda tertentu milik debitor atau pihak ketiga pemberi jaminanan.

Apabila debitor (pemberi fidusia) cidera janji, maka kreditor (pemerima fidusia) ini dapat langsung melaksanakan eksekusi. Ketentuan ini didasarkan pada Pasal 29 ayat 1(a) Undang-Undang Jaminan Fidusia yang merupakan pengaturan lebih lanjut dari Pasal 15 Undang-Undang Jaminan Fidusia, didasarkan pada title eksekutorial dalam Sertifikat fidusia yang tercantum kata-kata "Demi Keadilan Berdasarkan Ketuhanan Yang Maha Esa". Inilah yang memberikan titel eksekutorial yang mensejajarkan kekuatan akta tersebut dengan putusan pengadilan. Penjualan benda yang menjadi objek jaminan fidusia dapat dilakukan melalui lelang dimuka umum, dimungkinkan juga dilakukan penjualan dibawah tangan, asalkan hal tersebut disepakati oleh pemberi dan penerima fidusia. ${ }^{4}$

Salah satu kasus terkait dengan hal tersebut di atas yaitu s engketa antara konsumen berinisial ZSN dengan lembaga pembiayaan (PTAF). Dalam kasus ini, konsumen merasa dirugikan karena sepeda motor yang dibeli dengan bantuan lembaga pembiayaan tersebut disita karena menunggak pembayaran., PTAF mengutus seseorang sebagai debt collector untuk menyita sepeda motor tanpa memberikan tenggang waktu. Atas kejadian tersebut konsumen melakukan pengaduan. Untuk menyelesaikan permasalahan tersebut konsumen dibantu oleh Lembaga Perlindungan Konsumen Swadaya Masyarakat (LPKSM) Al-Jabbar.

\footnotetext{
${ }^{3}$ J. Satrio, Hukum Jaminan dan Hak-hak Kebendaan, Bandung, Citra Aditya Bakti, Bandung: 1991, hlm 319 52
} 


\section{Penyelesaian Sengketa Jaminan Fidusia oleh LPKSM Al-Jabbar}

Sebagaimana diketahui, ketika berbicara soal konsumen dan pelaku usaha tidak pernah lepas dari potensi sengketa. Cara penyelesaian sengketa konsumen dengan pelaku usaha, sebagaimana dalam Pasal 45 UUPKyaitu:

Pertama, Setiap konsumen yang dirugikan dapat menggugat pelaku usaha melalui lembaga yang bertugas menyelesaikan sengketa antara konsumen dan pelaku usaha atau melalui peradilan yang berada dilingkungan peradilan umum.

Kedua, Penyelesaian sengketa konsumen dapat ditempuh melalui pengadilan atau diluar pengadilan berdasarkan pilihan sukarela para pihak yang bersengketa.Ketiga, Penyelesaian sengketa di luar pengadilan sebagaimana dimaksud pada ayat (2) tidak menghilangkan tanggung jawab pidana sebagaimana diatur dalam undnag-undang.Keempat, Apabila telah dipilih upaya penyelesaian sengketa konsumen di luar pengadilan gugatan melalui pengadilan hanya dapat ditempuh apabila upaya tersebut dinyataan tidak berhasil oleh salah satu pihak atau oleh para pihak yang bersengketa.

Konsumen dapat digolongkan ke dalam tiga golongan, yaitu: ${ }^{5}$ ) Konsumen komersial (Commercial consumer) adalah setiap orang yang mendapatkan barang dan/atau jasa yang digunakan untuk memproduksi barang dan/atau jasa lain dengan tujuan mendapatkan keuntungan. b) Konsumen antara (intermediate consumer) adalah setiap orang yang mendapatkan barang dan/jasa yang digunakan untuk diperdagangkan kembali juga dengan tujuan mencari keuntungan. c) Konsumen akhir (ultimate consumer/end user) pengguna atau pemanfaat akhir dari suatu produk.

Atas pengelompokan tersebut, istilah konsumen dapat diartikan secara luas, yaitu semua pemakai maupun pengguna barang dan/jasa untuk tujuan tertentu. Istilah konsumen sebagai definisi yuridis formal ditemuan dalam Pasal 1 ayat (2) UUPKyang menyatakan bahwa konsumen adalah: "Setiap orang pemakai barang dan/atau jasa yang tersedia dalam masyarakat, baik bagi kepentingan diri sendri, keluarga, orang lain mapun makhluk hidup lain dan tidak untuk diperdagangkan." 
Pasal 1 angka (3) UUPK yang menyatakan bahwa Pelaku Usaha adalah: "Setiap orang perseorangan atau badan usaha, baik yang berbentuk badan hukum maupun bukan badan hukum yang didirikan dan berkedudukan atau melakukan kegiatan dalam wilayah hukum negara Republik Indonesia, baik sendiri maupun bersama sama melalui perjanjian menyelenggarakan kegiatan usaha dalam berbagai kegiatan ekonomi."

Pasal 1 ayat (4) UUPK yang dimaksud barang adalah: "Setiap benda baik berwujud maupun yang tidak berwujud, baik bergerak maupun yang tidak bergerak, dapat dihabiskan maupun tidak dapat dihabiskan, yang dapat untuk diperdagangkan, dipakai, dipergunakan, atau dimanfaatkan oleh konsumen. “

Adapun yang dimaksud jasa pada Pasal 1 ayat (5) UUPK mengatakan bahwa jasa adalah: "Setiap layanan yang berbentuk pekerjaan atau prestasi yang disediakan bagi masyarakat untuk dimanfaatka oleh konsumen."

Adapun hak-hak konsumen dalam Pasal 4 UUPK mengatakan sebagai berikut:

a) Hak atas kenyamanan, keamanan, dan keselamatan dalam mengkonsumsi barang dan/atau jasa;

b) Hak untuk memilih barang dan/atau jasa serta mendapatkan barang dan/atau jasa tersebut sesuai dengan nilai tukar dan kondisi serta jaminan yang dijanjikan,

c) Hak atas informasi yang benar, jelas, dan jujur mengenai kondisi dan jaminan barang dan/atau jasa,

d) Hak untuk didengar pendapat dan keluhannya atas barang dan/atau jasa yang digunakan,

e) Hak untuk mendapatkan advokasi, perlindungan, dan upaya penyelesaian sengketa perlindungan konsumen secara patut,

f) Hak untuk mendapatkan pembinaan dan pendidikan konsumen,

g) Hak untuk diperlakukan atau dilayani secara benar dan jujur serta tidak diskriminatif,

h) Hak untuk mendapatkan kompensasi, ganti rugi dan/atau penggantian, apabila barang dan/atau jasa yang diterima tidak sesuai dengan perjanjian atau tidak 
sebagaimana mestinyaHak hak yang diataur dalam ketentuan peraturan perundang- undangan yanglainnya.

LPKSM Al-JAbbar adalah lembaga non pemerintah yang terdaftar dan diakui keberadaannya oleh pemerintah yang mempunyai kegiatan menangani perlindungan konsumen. Pemerintah mengakui pembentukan LPKSM apabila telah memenuhi persyaratan diantaranya:

1. Terdaftar pada pemerintah kabupaten/kota;

2. Bergerak dibidang perlindungan konsumen sebagaimana tercantum dalam anggaran dasarnya;

3. Menyuarakan kepentingan konsumen;

4. LPKSM memiliki hak guagat dalam konteks litigasi kepentingan konsumen. Hak gugat tersebut dapat dilakukan oleh LPKSM yang telah memenuhi syarat, yaitu bahwa lembaga perlindungan konsumen telah berbentuk badan hukum atau yayasan yang dalam anggaran dasarnya memuat tujuan perlindungan konsumen.

Saat menjalankan tugasnya LPKSM Al-jabbar diatur pada Pasal 44 ayat (3) UUPK meliputi kegiatan:

a) Menyebarkan informasi dalam rangka meningkatkan kesadaran atas hak dan kewajiban dan kehati-hatian konsumen dalam mengkonsumsi barang dan/atau jasa;

b) Memberikan nasihat kepada konsumen yang memerlukannya;

c) Bekerjasama dengan instansi terkait dalam upaya mewujudkan perlindungan konsumen;

d) Membantu konsumen dalam memperjuangkan haknya, termasuk menerima keluhan atau pengaduan konsumen;

e) Melakukan pengawasan bersama pemerintah dan masyarakat terhadap pelaksanaan perlindungan konsumen.

LPKSM Al-Jabbar ketika menerima pengaduan dari konsumen sudah diatur dalam Pasal 44 ayat (2) UUPK bahwa LPKSM memiliki kesempatan untuk berperan aktif dalam mewujudkan perlindungan konsumen, dengan cara mendampingi konsumen untuk menyelesaikan sengketa yang dialami konsumen., Pendampingan itu juga bisa dilakukan dalam bentuk negosiasi maupun mediasi sesuai kesepakatan para pihak.

Saat memberikan pelayanan terkait dengan penanganan pengaduan permasalahan dari pihak konsumen yang datang, pihak Al- 
Jabbar mengutamakan asas tolong menolong, guna memberikan pertolongan bagi pihak konsumen yang mempunyai permasalahan serta membutuhkan bantuan.

Tahapan yang dilakukan LPKSM Al-Jabbar dalam memberikan perlindungan terhadap konsumen dalam kasus di atas diawali dengan mengajukan surat penangguhan kepada pelaku usaha, agar pelaku usaha tidak langsung mengambil obyek jaminan, karena konsumen tidak melakukan prestasinya.

Menurut masyarakat, keberadaan LPKSM sangat membantu, karena hak konsumen dapat diperjuangkan bersama LPKSM. LPKSM AlJabbar selalu membantu konsumen apabila terjadi sengketa antara konsumen dengan pelaku usaha. Ketika terjadi pengaduan ke Al-Jabbar, maka Al-Jabbar akan langsung menangani kasus tersebut. Lembaga tersebut memberikan jalan keluar semisal berupa pengbekupan obyek jaminan, dan/atau pengajuan penagguhan terhadap obyek jaminan tersebut kepada pelaku usaha. ${ }^{6}$

Apabila konsumen memilih pengbekupan, maka jaminan fidusia akan disimpan atau dititipkan di LPKSM. Sehingga ketika terjadi penyitaan terhadap jaminan fidusia oleh perwakilan pelaku usaha, mereka akan mendatangi LPKSM untuk mengambil objek jaminan., Pasa kesempatan tersebut, LPKSM akan melakuan negosiasi terkait sengketa tersebut. Pihak LPKSM akan meminta sertifikat fidusia atau putusan eksekutorial pengadilan terhadap obyek jaminan tersebut.

Apabila pelaku usaha tidak dapat menunjukan sertifikat atau putusan pengadilan, maka leasing tidak dapat melakukan eksekusi terhadap obyek jaminan karena tidak mempunyai kekuatan hukum tetap. Perwakilan pelaku usaha membawa oknum polisi untuk mengambil objek jaminan fidusia, namun tetap tidak bisa. Karena hal tersebut dianggap sebagai utang-piutang biasa dan bukan perjanjian fidusia, pihak Al-Jabbar dianggap telah melakukan penggelapan terhadap objek jaminan fidusia.

Meskipun demikian, objek jaminan tersebut tetap tidak dapat diambil, karena dari pihak Pelaku usaha tidak dapat menunjukan sertifikat atau putusan pengadilan bahwa objek jaminan tersebut dapat dieksekusi karena konsumen tidak dapat melakukan prestasinya.

\footnotetext{
${ }^{6}$ Berdasarkan hasil wawancara pribadi penulis dengan Bapak Yudi Pagar Alam selaku pimpinan LPKSM Al-Jabbar Kabupaten Sumedang, pada tanggal 15 juni 2017, Jam 21.00 WIB
} 
Bagi masyarakat dengan adanya LPKSM dapat membantu konsumen dalam menyelesaikan sengketa konsumen, dikarenakan LPKSM ada pada pihak konsumen, tetapi bagi pelaku usaha merupakan sebuah kerugian, karena LPKSM selalu melindungi konsumen. Pimpinan LPKSM Al- Jabbar berpendapat bahwa hak konsumen sangat penting. Apabila ada konsumen yang membutuhkan bantuan. LPKSM selalu siap untuk membantu dan memperjuangkan, karena yang menjadi objek jaminan dalam perjanjian fidusia adalah milik konsumen itu sendiri, karena dalam surat-suratnya atas nama konsumen. Apabila konsumen tidak mampu menjalankan prestasinya maka pelaku usaha harus memberian keringanan kepada konsumen, karena tidak setiap konsumen yang tidak melakukan prestasinya akan beritikad tidak baik, melainkan keadaan konsumen yang sedang pailit. ${ }^{7}$

Apabila konsumen meminta bantuan kepada LPKSM berupa Penangguhan konsumen haya membayar satu kali cicilan untuk 3-4 bulan itu akan mendapatkan jaminan, objek jaminan fidusia tidak akan diambil oleh pelaku usaha, itu dapat membantu konsumen, dari pada konsumen harus membayar kepada pelaku usaha atau konsumen tidak meminta bantuan kepada LPKSM, akan merugikan konsumen itu sendiri, LPKSM disini memberikan keringanan kepada konsumen, karena LPKSM membantu konsumen atas dasar tolong menolong.

Pasal 44 ayat (3) huruf (b) menyatakan bahwa LPKSM mempunyai tugas "memberikan nasihat kepada konsumen yang memerlukannya", dalam pasal 5 Peraturan Pemerintah Nomor 59 tahun 2001 tentang LPKSM, ditentukan bahwa pemberian nasihat kepada konsumen yang memerlukan di laksanakan oleh LPKSM secara lisan atau tertulis agar konsumen dapat melaksanakan hak dan kewajibannya. ${ }^{8}$

Penulis berpendapat bahwa LPKSM belum sepenuhnya memberikan nasihat kepada setiap konsumen. Dalam memberikan nasihat bukan hanya untuk melindungi hak konsumen, tetapi LPKSM juga harus memberikan nasiat kepada konsumen terkait kewajiban konsumen. Apabila LPKSM hanya memperjuangkan haknya tanpa melihat kewajiban konsumen maka itu semua akan memberikan peluang kepada konsumen, tidak sedikit konsumen yang meman-

7 Berdasarkan hasil wawancara pribadi penulis dengan Bapak Yudi Pagar Alam selaku pimpinan LPKSM Al-Jabbar Kabupaten Sumedang, pada tanggal 15 juni 2017, Jam 21.00 WIB.

${ }^{8}$ Ahmadi Miru dan Sutarman Yudo, hlm 222 
faatkan LPKSM untuk dijadikan pelindungnya, banyak konsumen lebih memilih menangguhkan objek jaminannya dari pada konsumen melakukan prestasinya, karena biaya penangguhan lebih murah dari pada konsumen harus membayar prestasinya.

Dalam melindungi hak konsumen, diharapkan LPKSM lebih teliti dalam menanggapi konsumen yang datang, jangan sampai keadaan LPKSM dimanfaatkan oleh para konsumen yang tidak mau melakukan prestasinya, meskipun dalam objek jaminan fidusia tercantum atas nama konsumen, itu bukan menjadi alasan bagi LPKSM dalam melindungi konsumen. LPKSM dapat memberikan nasihat apabila ada konsumen yang datang untuk meminta bantuan, bukan hanya berupa haknya saja, tetapi kewajibannya juga harus di perhatikan agar terciptanya konsumen yang mandiri dan menambah wawasan kepada konsumen.

Berdasarkan data sekunder, serta dikaitkan dengan hasil wawancara bersama pimpinan LPKSM Al-Jabbar Kabupaten Sumedang, terkait tugasnya dalam Pasal 44 ayat (3) huruf (b) UUPK, maka dapat dideskripsikan bahwa DPC Al-Jabbar Kabupaten Sumedang dalam menangani kasus pokok perkara pengaduan konsumen itu belum sepenuhnya sesuai dengan UUPK. LPKSM belum dapat memberikan pembinaan dan memberikan pendidikan bahwa perlu keseimbangan antara pemenuhan hak dan kewajiban baik konsumen maupun pelakku usaha. karena pada dasarnya apabila kewajiban konsumen sudah terpenuhi maka hak-hak konsumen pun akan terpenuhi. Sebagaimana dalam Pasal 4 huruf (f) yang menyatakan bahwa konsumen memiliki “ Hak untuk mendapatkan pembinaan dan pendidikan konsumen"

Apabila pelayanan LPKSM tetap seperti itu, dikhawatirkan akan banyak konsumen yang tidak melakukan kewajibannya dan memilih untuk meminta perlindungan kepada LPKSM. Sudahseharusnya LPKSM lebih bijaksana dan teliti dalam memberikan perlindungan kepada konsumen.

Ketika LPKSM melindungi konsumen, yang menjadi dasar ketika akan melindungi hak-hak konsumen LPKSM harus melihat KUHPer karena pada Pasal 1338 KUHPer yang menyatakan bahwa semua perjanjian yang dibuat secara sah, berlaku sebagai undang-undang bagi yang membuatnya. Ketentuan ini mengandung asas perjanjian bersifat terbuka, artinya, dalam menyelesaikan masalah, setiap orang 
bebas memformulasikannya dalam bentuk perjanjian yang isinya apapun untuk dapat dijalankan dalam rangka menyelesaikan masalah, selanjutnya sebagaimana ditentukan dalam Pasal 1340 KUHPerdata bahwa perjanjian hanya berlaku antara pihak-pihak yang membuatnya. ${ }^{9}$

\section{Hambatan dan Upaya LPKSM Al-Jabbar dalam Penyelesaian Sengketa Fidusia}

Saat melaksanakan apa yang telah diamanatkan UUPK kepada LPKSM untuk membantu pemerintah demi terlindunginya konsumen yang dirugikan akibat dari pelaku usaha, Az Nasution berpendapat bahwa hukum perlindungan konsumen merupakan bagian dari dari hukum konsumen yang memuat asas-asas atau kaidah-kaidah bersifat mengaturdan juga 10 mengandung sifat yang melindungi kepentingan konsumen. Dalam menjalankan tugas tersebut, ada beberapa hambatan-hambatan dalam melindungi hak konsumen terhadap eksekusi jaminan fidusia, yaitu Sebagai berikut:11

\section{Hambatan bersifat Internal}

Hambatan secara internal merupakan hambatan yang muncul dalam diri atau LPKSM Al-Jabbar sendiri, yang meliputi :12 Pertama, Keuangan/ financial yang kurang memadai. LPKSM Al-jabbar adalah lembaga perlindungan konsumen yang berbasis volunteer/relawan, maka demi terwujudnya perlindungan terhadap konsumen LPKSM membutuhkan dana untuk keperluan konsumen, dan untuk memberikan fasilitas yang memadai, untuk dana yang didapat juga terbatas hasilnya, padahal banyak kebutuhan yang harus dipenuhi oleh Al-Jabbar dalam mewujudkan terlindunginya hak-hak konsumen, supaya konsumen merasakan keamanan dalam mengkonsumsi barang atau jasa

Kedua, Waktu Pelayanan Tidak Tetap. Mengingat LPKSM Al-Jabbar adalah lembaga yang berbasis volunteer/relawan, maka para anggotanya pun memiliki kesibukan masing-masing, jadi tidak hanya

\footnotetext{
${ }^{9}$ Bambang Sutiyoso, Op.cit, hlm 11

${ }^{10}$ Shidarta, op.cit, hlm 11

${ }^{11}$ Berdasarkan hasil wawancara pribadi penulis dengan Bapak Yudi Pagar Alam selaku pimpinan LPKSM Al-Jabbar Kabupaten Sumedang, pada tanggal 16 Juni 2017, Jam 04.15 WIB

12 Berdasarkan hasil wawancara pribadi penulis dengan Bapak Yudi Pagar Alam selaku pimpinan LPKSM Al-Jabbar Kabupaten Sumedang, pada tanggal 16 Juni 2017, Jam 04.15 WIB
} 
fokus kepada LPKSM, tetapi mereka juga memiliki kegiatan diluar. Hal ini dapat penulis lihat ketika saat datang ke kantor Al-jabbar, waktunya tidak tetap, penulis pun melakukan wawancara pada waktu malam hari, dikarenakan ketua dan anggota kepengurusan tidak dapat on time di kantor, dan untuk bisa bertemu dengan kepengurusan harus membuat janji terlebih dahulu dengan orang yang bersangkutan.

\section{Hambatan yang Bersifat Eksternal ${ }^{13}$}

Pertama, Kurangnya pengetahuan para konsumen. Pemahaman konsumen terhadap haknya ini menjadi penting mengingat UUPK merupakan aturan dasar atau acuan dalam memahami dan melindungi hak-hak konsumen untuk mencegah pelanggaran yang dilakukan oleh pelaku usaha. Keterbatasan informasi menjadi kendala yang banyak dihadapi oleh konsumen, terutama informasi yang benar mengenai produk dan jasa yang di nikmati oleh konsumen, dan aturan dalam memberikan objek jaminan fidusia kepada pelaku usaha, padahal hak konsumen untuk mendapatkan informasi atau hak tahu konsumen merupakan hak yang paling esensi.

Kedua, Konsumen yang tidak mandiri. Masih banyaknya masyarakat yang menaruh harapan kepada LPKSM, padahal LPKSM adalah lembaga dengan keterbatasan sumber dayanya. Hal ini merupakan hambatan dalam membentuk konsumen yang cerdas, mandiri, kritis, dan mempunyai mental besar, seharusnya konsumen mampu melindungi dirinya sendiri serta mampu memilih dan menentukan barang dan/atau jasa yang akan digunakan dengan melihat berbagai aspek, seperti kualitas barang, isi dari perjanjian, dan lain sebgainya

Ketiga, Adanya oknum polisi yang membawa perkara keranah pidana. Mengingat banyak para pelaku usaha yang membawa oknum polisi dalam menjalankan sita jaminan fidusia, dengan tujuan untuk menakut-nakuti masyarakat dan oknum polisi selau menuduh LPKSM melakukan penggelapan terhadap objek jaminan, ketika konsumen meminta bantuan kepada pihak LPKSM, sehingga dengan adanya oknum polisi dapat menghambat kinerja LPKSM dalam melindungi hak konsumen.

${ }^{13}$ Berdasarkan hasil wawancara pribadi penulis dengan Bapak Yudi Pagar Alam selaku pimpinan LPKSM Al-Jabbar Kabupaten Sumedang, pada tanggal 16 Juni 2017, Jam 04.15 WIB. 
Dengan adanya hambatan yang dialami LPKSM dalam melindungi hak konsumen. Masalah konsumen tidak semata mata masalah oran per-orangan, tetapi merupakan masalah bersama dan masalah bersama dan masalah nasionl sebab dasarnya semua orng adalah konsumen. ${ }^{14}$ Demi terwujudnya Perlindungan konsumen tidak menjadikan LPKSM mundur dalam membantu pemerintah untuk mewujudkan perlindungan konsumen, karena banyak cara untuk menangani hambatanhambatan yang terjadi pada saat mewujudkan perlindungan konsumen, adapun upaya yang dilakukan LPKSM pada saat menyelesaikan sengketa jaminan fidusia, diantaranya sebagaiberikut. ${ }^{15}$

\section{Upaya Bersifat Internal}

Adapun upaya yang dilakukan LPKSM Al-Jabbar dalam menyelesaikan hambatan yang timbul dari lembaga itu sendiri, demi terwujudnya Perlindungan Hak konsumen, sebagai berikut :16

Pertama, Upaya yang dilakukan LPKSM Al-Jabbar dalam hal Keuangan. Keterbatasan Al-jabbar dalam hal financial tidak menyurutkan semangat untuk terus meningkatkan kesadaran konsumen dalam mempertahankan haknya. Untuk mengatasi keterbatasan financial Aljabbar melakukan upaya sebgai berikut : a) Meminta dana dengan mengajukan proposal kepada pemerintah untuk melakukan kegiatan terkait perlindungan konsumen. b) Menggalang dana dari masyarakat, dilakukan dengan cara menerima bantuan dana dari masyarakat konsumen yang meminta perlindungan dengan dana satu kali cicilan konsumen terhadap obyek jaminan. c) Melakukan iuran dari para pengurus Al-Jabbar

Kedua, Upaya yang dilakukan LPKSM Al-Jabbar dalam hal waktu yang tidak tentu. Untuk masalah waktu yang terbatas, anggota kepengurusan selalu berusaha mengadakan pertemuan, yang bertujuan untuk mempererat ikatan dan solidaritas para pengurus, serta meneguhkan pengabdian anggota kepada masyarakat, sehingga para anggota sesalu ingat dan meluangkan waktu untuk mencapai target yang diimpikan bersama. Tidak ada jadwal masuk yang di tetapkan oleh

\footnotetext{
${ }^{14}$ Janus sidabalok, Hukum Perlindungan Konsumen di Indonesia, PT. Citra Aditya Bakt, Bandung, 2014, hlm 4

${ }^{15}$ Berdasarkan hasil wawancara pribadi penulis dengan Bapak Yudi Pagar Alam selaku pimpinan LPKSM Al-Jabbar Kabupaten Sumedang, pada tanggal 16 Juni 2017, Jam 05.30 WIB

${ }^{16}$ Berdasarkan hasil wawancara pribadi penulis dengan Bapak Yudi Pagar Alam selaku pimpinan LPKSM Al-Jabbar Kabupaten Sumedang, pada tanggal 16 Juni 2017, Jam 05.30 WIB
} 
Al-Jabbar dalam hal waktu masuk kerja, tapi diwajibkan bagi setiap anggota masuk setiap hari, kecuali ada halangan yang tidak bisa di tinggalkan. Untuk waktu bertemu para anggota, biasanya diadakan 1 minggu 2 kali ataupun 1 minggu sekali di DPCAl-Jabbar.

\section{Upaya Bersifat Eksternal}

Selain hambatan yang bersifat internal, ada juga hambatan yang bersifat eksternal, yaitu hambatan yang datangnya dari luar, namun LPKSM Al-Jabbar menyadari hal itu semua, karena tidak mudah untuk melaksanakan apa yang di harapkan, demi terwujudnya harapan LPKSM maka LPKSM Al-Jabbar Kabupaten Sumedang melakukan beberapa upaya yang dapat mereka lakukan demi terwujudnya harapan LPKSM diantaranya $:^{17}$

Upaya LPKSM dalam memberikan pengetahuan kepada konsumen. Agar konsumen sepenuhnya memahami hak-hak mereka dalam UUPK, AL-Jabbar berusaha terus untuk melakukan sosialisasi, memberikan informasi yang benar kepada konsumen tentang keberadaan UUPK melalui berbagai kegiatan yang sifatnya terubuka untuk umum, dianataranya: a) Membuat brosur-brosur untuk disebarkan kepada masyarakat, tentang perlindungan hak konsumen, b) Melakukan seminar dan bekerja sama dengan pemerintahan setempat, seperti Desa, Kecamatan, dan instansi lain, untuk melakukan semiar terbuka bagi masyarakat, pelaku usaha dan instansi instansi.

Upaya LPKSM dalam mendorong Masyarakat yang Lebih Mandiri. Upaya LPKSM Al-Jabbar Kabupaten Sumedang dalam hal mendorong masyarakat yang cerdas, mandiri, dan kritis, Al-Jabbar terus berusaha membererikan pemahaman terhadap konsumen dalam berbagai kegiatan penyuluhan maupun mendampingi dengan memberikan penjelasan terait hak-hak dan kewajiban konsumen. Harapan disini adalah konsumen itu berdaya dan dapat melindungi diri sendiri, konsumen harus berpikir dan berhati hati dalam mengkonsumsi barang dan jasa, dan berhati hati dalam membuat suatu perajian, kemudian jika terjadi konflik atau sengketa dengan pelaku usaha atau barang yang dibeli tidak sesuai dengan apa yang diharapkan konsumen, atau terjadinya sengketa terhadap objek jaminan

\footnotetext{
${ }^{17}$ Berdasarkan hasil wawancara pribadi penulis dengan Bapak Yudi Pagar Alam selaku pimpinan LPKSM Al-Jabbar Kabupaten Sumedang, pada tanggal 16 Juni 2017, Jam 05.30 WIB
} 
fidusia, masyarakat dapat membela diri sendiri, karena tidak mungkin semua sengketa ditangani langsung oleh LPKSM

Upaya LPKSM dalam Mengatasi Oknum polisi yang mengaitkan perkara Perdata Keranah Pidana. Mengingat adanya hambatan ketika ada oknum dari Kepolisian yang ikut serta terhadap eksekusi jaminan fidusia, meskipun ada Peraturan Kapolri yang mengatur keterlibatan Polri dalam eksekusi jaminan fidusia, tetapi itu hanya sebatas pengaman saja tidak membawa sengketa konsumen keranah pidana, karena LPKSM menjelaskan bahwa pihak Kepolisian tidak berwenang terhadap perkara perdata, meskipun pihak Kepolisian dapat ikut serta dalam sita jaminan fidusia, itu hanya sebatas pengamanan saja, bukan untuk ikut serta dalam masalah perdata, dan pihak Kepolisian dapat ikut serta apabila terjadi pelanggaran pidana.

Apabila ada oknum Polisi yang membawa perkara tersebut ke ranah pidana maka LPKSM akan melaporkan oknum Polisi tersebut, apabila oknum Polisi dari Polsek, maka LPKSM akan melaporkannya ke Kapolres, apabila oknum polisinya dari Kapolres maka, akan dilaporkan ke Kapolda, demi terciptanya perlindungan konsumen LPKSM akan melakukan segala upaya, apa yang bisa di lakukan oleh LPKSM Al-Jabbar

\section{Penutup}

LPKSM Al-Jabbar memiliki peran besar dalam penyelesaian sengketa jaminan fidusia yang dihadapi oleh masyarakat di lingkungan lembaga tersebut. Metode penyelesaian mengedepankan negosiasi dan mediasi. Namun untuk tugas-tugas lain dari LPKSM yang didasarkan pada Pasal 44 ayat (3) huruf (b) UUPK dan Hak konsumen yaitu Pasal 4 (f) UUPK belum terlaksana dengan baik dimana LPKSM bertugas untuk melakukan pembinaan terhadap konsumen.

Hambatan yang dialami oleh lembaga dalam melindungi hak-hak konsumen di antaranya adalah masalah finansial, waktu, kurangnya pengetahuan, ketidak mandirian konsumen, serta adanya campur tangan oknum penegak hukum. Upaya yang dilakukan oleh LPKSM AlJabbar dalam melaksanakan tugasnya tersebut antara lain pemungutan biaya kepada anggota, pembagian waktu jaga, upaya memberikan pengetahuan bagi masyarakat, mendorong masyarakat agar lebih mandiri, serta melaporkan oknum penegak hukum kepada pihak yang berwenang. 


\section{DAFTAR PUSTAKA}

Abdulkadir Muhammad, Hukum Perdata Indonesia, Citra Aditya Bakti, Bandung, 2000

Ahmad Miru, Prinsip-Prinsip Perlindungan Konsumen di Indonesia, Raja Grafindo Persada, Jakarta, 2011

Amad Sudiro, dkk, 2014, Hukum dan Keadilan (aspek nasional \& internasional), Jakarta. PT.Rajagrafindo Persada.

Bambang Sutiyoso, Hukum Arbitrase dan Alternatif Penyelesaian Sengketa, Gama Media, Yogyakarta, 2008.

Gunawan Widjaja dan Ahmad Yani, Jaminan Fidusia, Grafindo Persada, Jakarta, 2000.

Intar Nur dan Rukiyah Lubis, Win-Win Solution Sengketa Konsumen, Pustaka Yustisia, Yogyakarta, 2014

J. Satrio, Hukum Jaminan dan Hak-hak Kebendaan, Bandung, Citra Aditya Bakti, Bandung: 1991,

Janus sidabalok, Hukum Perlindungan Konsumen di Indonesia, PT. Citra Aditya Bakti, Bandung, 2014

Purrwahid Patrik dan Kashadi, Hukum Jaminan,Fakultas Hukum, Universitas Diponegoro, Semarang, 2008

Sanusi Bintang dan Dahlan, Pokok-Pokok Hukum Ekonomi dan Bisnis, PT. Citra Aditya Bakti, Bandung, 2000

Shindarta, Hukum Prlindungan Konsumen Indonesia, Grasindo, Jakarta, 2006.

Subekti, Hukum Perjanjian,Cetakan Keempat, Intermasa, Jakarta, 1979, hlm 1.

Zulham, Hukum Perlindungan Konsumen, Kencana Prenada, Jakarta, 2013. 
122 | 'Adliya Vol.12, No. 2, Juni 2018 